\title{
Biblioteker og kunstmuseer som kulturarvsinstitutioner
}

\author{
Af Anders Ørom
}

\section{Kanoniseret kulturarv og kulturarv i et bredere perspektiv}

Bibliotekerne og kunstmuseerne er "Memory institutions" - eller med et lidt anderledes fransk udtryk "Lieux de mémoire", steder for erindring og dannelse, institutioner for forvaltning og konstruktion af kulturarv. Artiklen fokuserer på den kulturarv, der i Danmark forvaltes og formidles af biblioteker og kunstmuseer. Forståelsen af begrebet og forvaltningen af kulturarven er af historiske og institutionelle grunde forskellige på kunstmuseumsområdet og biblioteksområdet.

Artiklen indledes med en præsentation og diskussion af kulturarvsbegrebet set i relation til de to typer af institutioner og i relation til den aktuelle kulturpolitik. Herefter følger en kortfattet historisk fremstilling, hvis sigte det er at analysere forholdet mellem en national og en europæisk/-universel forståelse af kulturarven. Det er artiklens tese, at kunstmuseerne i langt højere grad end bibliotekerne har været en del af det nationale projekt, der etableredes i begyndelsen af 1800 tallet. I forlængelse af 1800tallets nationale projekt har betydningen af den nationale kulturarv været stærkt accentueret på de danske kunstmuseer gennem det meste af 1900 talet. I modsætning hertil har bibliotekerne først og fremmest været funderede i en europæisk oplysningstradition. Ingen af disse to udviklingslinjer har været uden brud- flader; men brudfladerne sætter udviklingslinjerne i relief.

Begrebet kulturarv er et nyere begreb, der først for alvor er blevet institutionaliseret efter år 2000, hvilket illustreres af, at Den Store Danske Encyklopadis artikel om "Kulturarv" først blev trykt i supplementsbindet. Artiklen starter med en bred definition og udskiller derefter den kanoniserede finkultur.

"Kulturarv, kulturprodukter, der i særlig grad udg $\varnothing$ r et lager for menneskelig erfaring, og som derfor tvinger til eftertanke og er med til at forme en kulturel identitet. I den snævre betydning er der tale om en kanoniseret kultur, såkaldt finkultur, der kun omfatter malerkunst, arkitektur, litteratur og musik, som er anerkendt i elitær forstand. (Den Store Danske Encyklopadi, Supplementsbind, 2002, side 391).

Citatet fortsætter:

"Begrebet bruges dog stadig mere i en bred betydning fra kunstneriske og hverdagslige materielle udtryk til sprog, livsformer og identitet." (Ibid.)

I encyklopædien opereres der implicit med et finkulturelt og et antropologisk kulturbegreb. Det 
førstnævnte knytter sig til den kanoniserede kultur, der får sin status gennem en udvælgelses- og vurderingsproces, hvis udgangspunkt er institutionaliserede kvalitetskriterier. Når talen er om dansk kultur aktuelt, er der et skel mellem de danske kulturprodukter, der får status af kulturarv i kraft af eksempelvis kunstmuseernes og bibliotekernes vurdering og udvælgelse, og de kulturprodukter, der er "født" kulturarv i og med, at de er skabt i Danmark. Selvom de kanoniserede kulturprodukter i definitionen ovenfor knyttes særligt til dannelsen af identitet, er der i den aktuelle kulturpolitiske diskussion en tendens til også at sammenkoble "fødte" danske kulturprodukter og identitetsdannelse.

Skematisk kan kulturarv i kunstmuseums- og bibliotekssammenhæng fremstilles således:
Den kategorisering af kulturarven, der fremstilles i figur 1, er udtryk for denne artikels teser og problemstillinger. Den første tese er, at den nationale kulturarv har været hovedfundamentet for de danske kunstmuseer gennem det meste af 1900tallet. Den anden tese er, at bibliotekerne (nationalbiblioteksfunktioner undtaget) i samme periode har været funderede i en europæisk og universel oplysningstradition. De danske kunstmuseers nationale og bibliotekernes europæisk-universelle kontekster for kulturarv vil endvidere kort blive unders $\emptyset \mathrm{gt}$ med hensyn til deres historiske udspring før det 20. århundrede.

Med hensyn til den "fødte" kulturarv er der, udover det bredere spektrum af medieprodukter, historisk set sket det, at den nu eksplicit opfattes og forstås som kulturarv. Det er først i det seneste årti Det kongelige Bibliotek har forstået sig selv som en kulturarvsinstitution (i forhold til pligtafleveringen). Denne ændring i hvad kulturarven omfatter og spørgsmålet om hvorfor kulturarven aktualiseres lægger op til en kort kulturpolitisk belysning, der foretages i det følgende afsnit.

\begin{tabular}{|c|c|c|}
\hline$\underset{\text { Kulturarvskontekst }}{\downarrow}$ & $\begin{array}{l}\text { Dokumenter og varker der gennem udval- } \\
\text { gelse gøres til kulturarv ud fra faglige vær- } \\
\text { di- og vurderingskriterier }\end{array}$ & $\begin{array}{l}\text { Dokumenter og varker der er 'født' kul- } \\
\text { turarv i og med at de er offentliggjort i } \\
\text { Danmark }\end{array}$ \\
\hline National kontekst & $\begin{array}{l}\text { Kernen i de klassiske kunstmuseers samlin- } \\
\text { ger } \\
\text { - nationalt orienteret kulturarvsbegreb } \\
\text { Traditionen i kunstmuseerne er national }\end{array}$ & $\begin{array}{l}\text { Kulturarven, der pligtafleveres til } \\
\text { Det kongelige Bibliotek og } \\
\text { Statsbiblioteket: } \\
\text { Den trykte kulturarv, } \\
\text { Kulturarven i lyd- og billedmedier } \\
\text { Den elektroniske kulturarv }\end{array}$ \\
\hline $\begin{array}{l}\text { Europaisk (universel) } \\
\text { kontekst }\end{array}$ & $\begin{array}{l}\text { Folkebibliotekernes samlinger - europæisk/ } \\
\text { vestligt orienteret kulturarvsbegreb } \\
\text { Traditionen på folkebibliotekerne er uni- } \\
\text { versel } \\
\text { Nyere kunstmuseers samlinger (Louisiana } \\
\text { og Arken) } \\
\text { Nyere særudstillinger på eksempelvis } \\
\text { Statens Museum for Kunst }\end{array}$ & $\begin{array}{l}\text { (Værker af europæisk eller internationalt } \\
\text { orienterede nyere danske kunstnere, der } \\
\text { qua det at de er danske og anerkendte } \\
\text { inden for kunstinstitutionen, gøres til kul- } \\
\text { turarv; jf. bl.a. Det digitale Studiearkiv. } \\
\text { Her er der tale om en kombination af } \\
\text { født og udvalgt kulturarv.) }\end{array}$ \\
\hline
\end{tabular}

Figur 1: Kanoniseret contra "født" kulturarv på kunstmuseer og i biblioteker 


\section{Kulturarv i den kulturpolitiske diskurs}

Begrebet kulturarv blev først for alvor anvendt som kulturpolitisk term i 1980erne. Forud for brugen af dette begreb gik brugen af begreber som 'identitet' og 'kollektiv hukommelse'. Fra 1980erne er såvel brugen som betydningen af begrebet kulturarv ekspanderet stærkt i den kulturpolitiske og institutionelle diskurs. I modsætning til interessen i 1960erne for den europæiske (samt i mindre grad den kristne og den norrøne) kulturarv, er der i det sidste tiår blevet fokuseret på "den danske kulturarv", på "Danmarks kulturarv". Bevaring af kulturarven og forskning i fortiden har med vekslende betoning været tillagt betydning for dansk identitet, uanset hvilke begreber der er blevet brugt om fænomenerne. Der har været (og er) naturligvis forskel på, hvilken fortid og hvilken identitet, der er konstrueret og som konstrueres gennem bl.a. kunstmuseers og bibliotekers forvaltning af kulturarven; men den kulturpolitiske diskurs reflekterer kun i begrænset omfang disse forskelle.

I forbindelse med EF-afstemningen i 1972 dukker der artikler op, der fokuserer på den danske kulturarv - i implicit modsætning til den europæiske. Den danske kulturarv blev således tematiseret i en (kultur)politisk kontekst, hvor modstanden mod integration i EF måtte tolkes som det styrende. Senere er det blevet modstanden mod den kulturelle globalisering, der har været hovedfiguren i en argumentation for den danske kulturarvs betydning. Sideløbende med de sidste års kulturpolitiske fokusering på den danske kulturarvs betydning, og især dens betydning for vores nationale identitet, har der været mange markeringer af, at den danske kultur må ses i en europæisk sammenhæng. Et eksempel på billedkunstens område finder i vi Allis Hellelands forord til udstillingen Avantgarde $i$ dansk og europaisk kunst 1909-19 på Statens Museum for Kunst. (Aagesen, 2002). Allis Helleland skriver:

"Det er vigtigt at se danske kunstnere i en tidsmæssig sammenhæng med kunstnere fra det $\emptyset$ vrige Europa, på tværs af grænser og sprog og ikke som et isoleret dansk fænomen. Statens Museum for Kunst har nu gennem en årrække som en vigtig del af museets handlingsplan arbejdet på at få perspektiveret den danske kunst i en europæisk sammenhæng." (Aagesen, 2002,7).

Statens Museum for Kunst lægger her vægt på den europæiske sammenhæng. Mange nulevende avantgardekunstnere forstår sig selv og deres værker i en international sammenhæng. Men accentueringen af en europæisk og international sammenhæng for danske kunstmuseer og kunstnere slår kun i begrænset omfang igennem i den aktuelle kulturpolitiske diskurs, hvor det først og fremmest er den danske kulturarvskontekst, der fremhæves.

Sammenkoblingen af kultur, kulturarv og dansk identitet var et centralt tema for de radikale kulturministre sidst i 1990erne. I Ebbe Lundgaards og den daværende regerings redegørelse til Folketinget om Kulturpolitik, 4. november 1997 siges det bl.a., at kulturens overordnede funktion er at fastholde og styrke dansk identitet overfor den internationale underholdningsindustri. Kunsten tillægges en særlig funktion i forhold til kulturarven, der i nogen grad forstås som noget dynamisk:

\footnotetext{
"Når vi skal udvikle og fastholde en dansk identitet i det moderne samfund, spiller kunsten også en afgørende rolle som spejl af nutid og fortid og pejlemærke for fremtiden. I de forskellige kunstarter stilles hele tiden uventede spørgsmål, og der skabes nye visioner, som kan inspirere den samfundsudvikling, der præges af hurtige og ofte drastiske forandringer." (Regeringens redegørelse til Folketinget om kulturpolitik, 1997)
}

Ud over den historiske og aktuelle "spejlfunktion" er kunsten også af betydning for vores forståelse af fremtiden. Gennem kunsten skal kulturarven bringes i dialog med nutiden.

Et par år senere fremlagde daværende kulturminister Elsebeth Gerner Nielsen kulturarv og dansk identitet som fokuspunkter i regeringens politik.(1) Hovedtrækkene i ministerens argumentation var, at der i en tid med opbrud, atomisering og bevægelse bort fra en fælleskultur gennem kulturen skulle skabes en ny fælles referenceramme. Kulturarven blev gjort til grundlaget for orientering i det flertydige samfund og denne skulle sam- 
men med dansk identitet sikre, at Danmark ikke skulle blive et "datterselskab" af globaliseringen. Kulturen og kulturarven blev i et dobbeltgreb gjort fundamental for samfundsudviklingen og for styrkelsen samt udviklingen af dansk identitet. Også den nuværende kulturminister Brian Mikkelsen synes at have fortsat denne linie.

\section{Kunstmuseerne og kulturarven}

Kunstmuseernes genstandsområde er den kanoniserede visuelle kunstneriske kulturarv. Et genstandsområde disse museer i høj grad medvirker til at konstruere via indk $\varnothing \mathrm{b}$ af og forskning $\mathrm{i}$ kunst. Ligesom de kulturhistoriske museer har kunstmuseerne en lovbestemt forpligtelse overfor den nationale kulturarv. Af Museumsloven (2001) fremgår det, at sikring af Danmarks kulturarv, adgang til den og formidling af viden om den er helt centrale formålsbestemmelser. Opfyldelsen af disse formål forudsætter indsamling, registrering, bevaring og forskning. Det er eksplicit pålagt kunstmuseerne at udvikle og tilgængeligg øre dokumentation.

Som noget nyt i museumslovgivningen fik hvert kulturområde i den nye lov af 2001 et særskilt afsnit. Om kunstmuseerne hedder det bl.a.: "§ 6 . Kunstmuseerne belyser billedkunstens historie og aktuelle udtryk samt dens æstetiske og erkendelsesmæssige dimensioner". For den danske kunsts vedkommende skal museerne anlægge og opretholde repræsentative samlinger.

Kravet om at belyse billedkunsten i nogle af dens centrale aspekter implicerer betydningen af forskning, og sammenholdt med den generelle formålsbestemmelse for museerne understreger det betydningen af forsknings- og formidlingspublikationer, herunder udstillingskataloger og implicit betydningen af museernes biblioteker.

Læst i lovens kontekst (sikring af Danmarks kulturarv) omfatter forpligtelsen både billedkunstens historie og aktuelle udtryk mere generelt. Der er således både tale om forvaltning af billedkunsttraditionen $o g$ om samtidsorientering. Forpligtelsen overfor kunstens historie, den kunsthistoriske forskning og formidlingen af deres faste samlinger er i første instans kunstmuseernes opgave. Med hensyn til dokumentationsfunktionen suppleres de af fagbiblioteker som Kunstakademiets Bibliotek. Her rækker dokumentationen af dansk kunst langt ud over, hvad der produceres og formidles på kunstmuseerne. Bl.a. ligger dokumentation af samtidig dansk kunst i Kunstakademiets Biblioteks regi. Ud over dettes og andre fagbibliotekers samlinger af udstillingskataloger og andre dokumenttyper vedrørende danske kunstnere er der sat særlig fokus på dokumentation af dansk samtidskunst gennem det studiearkiv, som Center for Dansk Billedkunst, der er en selvejende institution etableret af Kulturministeriet, har opbygget over nulevende danske kunstnere. Studiearkivet er projekteret fortsat i Det Digitale Studiearkiv, et projekt under Center for Dansk Billedkunst, der præsenterer sig som:

"(...) et dokumentationsarkiv, hvor udbredelsen, men også bevaringen af den danske kulturarv er i fokus. Arkivets betydning for eftertiden kan ikke undervurderes i og med vi indsamler stort set alt væsentligt materiale (kataloger, bøger, dias, videoer m.m.) over danske kunstnere." (Det Digitale Studiearkiv).

I Det Digitale Studiearkiv er kulturarv således også et centralt begreb; men opfattelsen af det danske er hverken knyttet til bestemte traditioner eller til en nationalromantisk farvet opfattelse af dansk kunst, som det historisk har været tilfældet med kunstmuseerne. På et bredere område, der supplerer kunstmuseerne, er Det Digitale Studiearkiv også med til at skabe - og udvide - kulturarven. Den planlagte dokumentation og formidling på Internettet skal repræsentere "nutidskunstens mange udtryksformer": reproduktion af enkelte værker, performanceoptagelser, kunst, der laves direkte til nettet m.v. Med formuleringen "alt væsentligt materiale (...) over danske kunstnere" udtrykkes det, at kriteriet for indsamling og bevaring ikke er en udvælgelse af kunstværker ud fra snævert elitære kriterier, jf. encyklopædiens formulering ovenfor. Hvad der produceres af (anerkendte) danske kunstnere må principielt forstås som kulturarv. Studiearkivet dokumenterer i princippet hele denne kulturarv, hvilket gør spektret af billedkunstnerisk, dansk kulturarv meget bredere end den elitære del af kulturarven, der forvaltes af kunstmuseerne. 
På billedkunstens område spænder kulturarven over et bredt spektrum af kunstens genrer og udtryksformer. Fra guldaldermalerier til digitalkunst, fra den traditionsbaserede kunst, der opfattes som kulturarv med nationalromantiske konnotationer, til samtidskunsten som medium for filosofisk refleksion og dialog med samfundet, fra de historisk repræsentative samlinger på Statens Museum for Kunst til nogle af samme museums separatudstillinger og kunstmuseet Arkens tematisering af dansk kunst $i$ et internationalt perspektiv. I denne overgribende diskurs om den billedkunstneriske kulturarv er der en modsætning mellem en nationalromantisk - æstetisk farvet kunstopfattelse og den samtidige, erkendelsesorienterede og internationalt relaterede forståelse af kulturarv og en tilsvarende modsætning mellem forskellige forståelser af kulturarvens historiske horisont.

På kunstmuseumsområdet har der - selv om selve termen kulturarv først er blevet brugt i Museumsloven fra 1984 - fra kunstmuseernes oprettelse været tale om indsamling, bevaring og formidling af kulturarv, og specielt af national kulturarv. Gennem betoningen af det nationale og gennem principperne for formidling, herunder specielt ordnings- og udstillingsprincipper, indskriver kunstmuseerne sig i den generelle museumshistorie.

I en leder i museumsbladet Indtryk skriver direktøren for Statens Museum for Kunst, Allis Helleland, sig ind i den aktuelle kulturpolitiske diskurs, dog med en understregning af udvekslingen mellem dansk og europæisk kunst:

\begin{abstract}
"Gennem de seneste år har perspektiveringen af den danske kunst til den europæiske været bestemmende for Statens Museum for Kunsts indsamling, forskning og formidling. (...) Jeg håber, at vi i vores arbejde med den danske kulturarv kan være med til nogle fælles referencerammer og en fælles forestilling om fremtidens samfund, så vi som danskere er bedre rustede til at operere som kosmopolitter." (Helleland, 2000, 2).
\end{abstract}

Helleland formulerer sig på den ene side i overensstemmelse med den kulturpolitiske diskurs, på den anden side sætter hun dansk kunst ind $\mathrm{i}$ en europæisk kontekst.

\section{Bibliotekerne og kulturarven før 1950}

Vender vi blikket mod bibliotekerne, er der flere forhold, som springer i øjnene. I modsætning til Museumsloven (2001) indeholder Biblioteksloven (2000) på det overordnede plan ingen formuleringer, der bestemmer bibliotekernes mål og opgaver $\mathrm{i}$ forhold til kulturarven. Siden Danmarks første bibliotekslov (Lov om statsunderstøttede Biblioteker, 1920) har folkebibliotekernes opgaver og mål været formuleret i almene termer. If $\varnothing l g e$ den første danske bibliotekslov fra 1920 ydes der et grundtilskud til "de Biblioteker hvis opgave er at udbrede Kundskaber og almindelig Oplysning." (Lov, 1920, § 4).

Den aktuelle bibliotekslov bestemmer folkebibliotekernes formål i tråd med traditionen fra 1920, men indeholder også en tilføjelse om kulturel aktivitet, der går tilbage til biblioteksloven fra 1964:

"§ 1. Folkebibliotekernes formål er at fremme oplysning, uddannelse og kulturel aktivitet ved at stille bøger, tidsskrifter, lydbøger og andre egnede materialer til rådighed såsom musikbærende materialer og elektroniske informationsressourcer, herunder Internet og multimedier." (Lov 2000).

Som det fremgår af $\S 2$, skal materialerne vælges ud fra kvalitets-, aktualitets- og alsidighedskriterier, der skal forstås i forhold til den encyklopædiske orientering, som har været det overordnede perspektiv for danske folkebiblioteker siden 1920. Inden for dette overordnede perspektiv var der for sk $\varnothing$ nlitteraturens vedkommende (i Bekendtgørelse vedrørende Lovens Gennemførelse af 1921) stillet et krav om at det statsunderst $\varnothing t t e d e$ bibliotek skulle indeholde, hvad der kan modsvare Danmarks litterære kulturarv. Et krav der var udtryk for datidens kanoniske opfattelse af dansk litteratur, jf. den sidste passus i citatet nedenfor. I bekendtgørelsen fra 1921, hvor der skelnedes mellem faglitteratur og skønlitteratur, var der ikke stillet et tilsvarende krav til faglitteraturen:

"Bibliotekets Bogbestand skal være alsidig sammensat. Den skal indeholde en Samling af oplysende Litteratur af geografisk, historisk og 
almindelig kulturhistorisk Art, Bøger om religiøse Spørgsmål, Samfundets Ordning, Naturkundskab og de praktiske Erhverv. Paa Skønlitteraturens Omraade skal Biblioteket kunne give Læseren Adgang til det bedste af den danske Litteraturs Frembringelser." (Lov, 1920, Bekendtg $\varnothing$ relsen $\S 3$, stk. b).

I forhold til kulturarv er historie, kulturhistorie, kunstarternes historie, sproghistorie og skønlitteratur centrale områder. På skønlitteraturens område kan udlån og bestand på Det nordjyske Landsbibliotek give nogle indikationer på situationen før 1920. I 1913/14 var der i bibliotekets samling 35\% skønlitteratur på dansk, svensk og norsk. Procentdelen af udenlandsk litteratur i oversættelse var ca. 19. Udlånsandelene var henholdsvis $46 \%$ og 21\%. (Boel, 1995, 80). Tyngdepunktet i udlånet af dansk, svensk og norsk skønlitteratur lå uden for dannelseslitteraturen, ligesom tyngdepunktet i udlånet af oversatte forfattere lå uden for verdenslitteraturens klassikere. Værker af Hall Caine og J. F. Cooper var de mest udlånte. Af skandinaviske forfattere var Ingeborg Vollquartz og Jeppe Aakjær genstand for størst lånerinteresse. (Boel, 1995, 81). Udlånsmønstret skyldtes ikke, at den kanoniske danske og udenlandske litterære kulturarv ikke fandtes på biblioteket. På dette punkt levede Det nordjyske Landsbibliotek op til den senere bekendtg $\varnothing$ relses krav samtidigt med at skønlitteraturen var repræsenteret på andre niveauer end dannelseslitteraturens.

Biblioteksdirektør Th. Døssings overblik fra 1929 over folkebibliotekernes historie, aktuelle situation og betydning for det folkelige oplysningsarbejde lå i forlængelse af bekendtgørelsens formuleringer og præciserer nogle forhold. Om bogbestanden skrev han:

"Det ligger i Sagens Natur, at et folkeligt Oplysningsarbejde i Hovedsagen må arbejde med Litteratur paa Modersmålet, og i Danmark, hvor de fleste Byer er smaa, vil det af $\varnothing$ konomiske Grunde være umuligt for de fleste Biblioteker at anskaffe den nødvendige Litteratur paa Fremmedsprog.” (Døssing, 1929, 237).

To forhold kan fremhæves ud fra dette citat: For det første er der tale om litteratur på dansk og ikke om dansk litteratur; for det andet tales der om den nødvendige litteratur på fremmedsprog. Døssing skrev endvidere, at udenlandsk litteratur "var et stadigt mere paatrængende Problem." (238). Videre hed det, at bibliotekssamlingen skulle indeholde den bedste litteratur for børn og unge, god skønlitteratur af "alle Arter" og i tilslutning hertil:

"oplysende og belærende geografisk og historisk Læsning, i første Række Rejsebeskrivelser og Levnedsskildringer. Fremdeles et alsidigt udvalg af Skrifter om æstetiske, kulturelle, sociale og religiøse forhold med Hovedvægten lagt paa Landets egen Historie og Kultur. Endelig et Udvalg af de nyeste og bedste Bøger om Naturkundskab og Vejledninger i det praktiske Erhvervsliv: Landbrug, Handel, Haandværk og Industri." (Døssing, 1929, 238)

Med hensyn til skønlitteratur er der ingen fremhævelse af den nationale litteratur. Det nationale kommer ind i den anden faglitterære hovedkategori (historie og kultur). Inden for denne kategori burde hovedvægten iflg. Døssing lægges på dansk historie og kultur. Det nationale er således betonet inden for centrale dele af kulturarven; men det er underordnet $\mathrm{i}$ forhold til det alsidige og encyklopædiske formål med samlingen.

Et enkelt eksempel kan belyse konsekvenser af 1920-loven for samlingen af faglitteratur. I forbindelse med at Hjørring bibliotek var blevet centralbibliotek i 1921 skete der en større vækst i geografisk, historisk, kulturhistorisk og religiøs litteratur samt i antallet af rejsebeskrivelser. Med hensyn til den historiske og kulturhistoriske litteratur blev der lagt mere vægt på Europas historie og oldtidscivilisationerne. (Emerek, 2001, 81). Der kan ikke generaliseres ud fra dette; men eksemplet indikerer, at en voksende interesse for Europa og Europas kulturhistorie kan have sat sit præg på folkebibliotekernes bogk $\varnothing \mathrm{b}$ i mellemkrigstiden.

Døssings artikel om folkebiblioteker blev under Besættelsen udgivet i en ændret og ajourført version (Døssing, 1942). Danmarks historiske situation taget i betragtning kunne man forestille sig, at Døssing fokuserede mere på det nationale som en 
implicit markering af kulturel modstand mod besættelsesmagten. I den revidere formulering af formålet fremhæves dansk skønlitteratur; men den sidestilles med oversættelser af udenlandsk skønlitteratur.

"Folkebibliotekerne har til Formaal at tjene almindelig Oplysning i alle Samfundslag, og deres vigtigste Bogmateriale er derfor den populærvidenskabelige Litteratur, d. v. s. Bøger, som fremstiller Forskningens resultater i almentilgængelig Form. Hertil kommer den lige saa vigtige Opgave at anskaffe et Udvalg af den bedste danske Skønlitteratur og Oversættelser til dansk fra fremmede Litteraturer." (Døssing, 1942, 207).

Biblioteksdirektøren så det som et problem, at de fleste af folkebibliotekernes benyttere ikke læste fremmede sprog. Det ikke direkte udtalte ideal for den "almindelige Oplysning" var at folkebibliotekernes oplysningsunivers burde indbefatte litteratur på fremmedsprog. Da dette kun kunne realiseres på større biblioteker og gennem lån fra Statsbiblioteket (som folkebibliotekernes "Overcentral") og andre biblioteker, måtte:

"Hovedvægten lægges paa dansk, d. v. s. dansk, norsk og svensk Litteratur og for andre Litteraturers Vedkommende paa Oversættelser til disse Sprog.” (Døssing, 1942, 208).

Døssing kan således ikke tillægges nationalistiske grunde til at lægge hovedvægten på litteratur på dansk, der udvides til skandinaviske sprog, men praktisk oplysningsmæssige.

\section{Folkebibliotekerne og kulturarven efter 1950}

Bibliotekar Niels Kunov udgav i 1952 den indtil da mest omfattende danske vejledning i principper for bogvalg og bestandsopbygning for folkebiblioteker. Hans encyklopædiske syn på faglitteraturen var i god overensstemmelse med Døssings og kan som dennes placeres i en europæisk/universel oplysningstradition. Kunov formulerede sine synspunkter i forhold til hovedgrupperne inden for kundskabsuniverset: Historie, personalhistorie, geografi og rejser, matematik og naturfag, lægekunst, sundhedslære, teknik og praktiske fag, samfundskundskab, pædagogik, folklore, filosofi, psykologi, okkultisme, religion, litteratur, sprog, kunst, spil og sport. Hertil kom skønlitteratur. For tre hovedgruppers vedkommende: historie, geografi og sprog understregedes betydningen af det nationale; men hovedsynspunktet var ikke nationalt. Om den historiske litteratur står der:

"Det må være et hovedsynspunkt, at læserne bør forsynes med den historiske litteratur, der kan give dem et grundlag for forståelsen af deres egen tids samfunds- og kulturforhold. Det indebærer, at der må lægges vægt på den nyere og nyeste tids historie og på fædrelandshistorien." (Kunov, 1952, 41).

Det oplysningsmæssige hovedsynspunkt havde sit udgangspunkt i en forståelse af samtiden, og fædrelandshistorien er et af midlerne til at nå denne forståelse. Fædrelandshistorier måtte sammen med almindelige verdenshistorier og kulturhistorier høre til grundstammen i ethvert bibliotek. De to bind af Den store mønsterkatalog dækker tilsammen den dansksprogede del af den litteratur, Kunov forholder sig til. Kronologisk dækker katalogerne litteraturen til og med 1955. Arbejdet på mønsterkatalogen blev startet i et udvalg under Statens Bibliotekstilsyn med henblik på folkebibliotekerne. Kunov deltog i dette arbejde, hvis mål var at skabe en selektiv bibliografi over faglitteratur på dansk, ikke en mønsterkatalog i almindelig forstand.

Den store mønsterkatalog har nedenstående definition og afgrænsning af dansk faglitteratur:

"Ved dansk litteratur forstås værker af bøger af danske forfattere, heri indbefattet en del værker skrevet på fremmede sprog, samt udenlandske forfatteres til dansk oversatte værker." (Den store mønsterkatalog, 1965, III).

På grund af den langsomme forældelsesgrad har historiske fremstillinger (inden for de egentlige historiske fag, kulturhistorie, litteraturhistorie og kunsthistorie) en overvægt. Ved at unders $\varnothing g e$ profilen af de historiske fremstillinger kan man få et indblik i orienteringen inden for denne del af formidlingen af kulturarven. Der er 18 fremstillinger af verdenshistorien og 17 brede kulturhistoriske 
fremstillinger. Dækningen af historiske perioder omfatter oldtiden (Orienten, jødefolket, Æggypten, Assyrien og Babylonien, Persien m.fl.), den klassiske oldtid (Grækenland og Rom, der er bedst dækket litteraturmæssigt), Middelalderen, Renæssancen og nyere tid samt det 19. og det 20. århundrede. Profilen i de generelle historiske fremstillinger er koncentreret om Europas historie og historiske rødder. Det samme mønster aftegner sig for de nationale historiefremstillingers vedkommende. For Danmarks vedkommende finder man naturligvis den største og mest differentierede mængde historiske værker; men dækningen af Norden og af Frankrig, England, Tyskland, Italien, Sovjetunionen og USA er også omfattende. For kunsthistoriens vedkommende har profilen omtrent samme karakter; men hvad angår enkeltkunstneres dominerer de danske, hvilket kan tolkes i lyset af kunstinstitutionens koncentration om dansk kunst. Inden for litteraturhistorie er der ved siden af studier i dansk litteratur mange værker om den europæiske del af verdenslitteraturen, herunder især græsk-romersk, fransk, engelsk, tysk, nyere nordisk, oldnorsk og oldislandsk. Fortsættelsen Den store mønsterkata$\log 2$ dækker litteratur udkommet i perioden 1941-55. Inden for en række litteraturområder er der sket en udvidelse og differentiering af vidensuniverset både med hensyn til religion, geografi, litteratur, sprogvidenskab og historie. I dette bind som i det første er der medtaget mange oversættelser af græsk og latinsk samt norrøn litteratur.

Helhedsvurderingen af mønsterkatalogerne er, at de har et afbalanceret forhold mellem det nationale og det europæiske. Anderledes formuleret kan det konkluderes, at det nationale kan ses i en nordisk og en europæisk kontekst, hvor den førstnævnte har rod i oldnordisk kultur og den sidstnævnte i (antik) græsk-romersk kultur, hvilket er i overensstemmelse med den europæisk/universelle oplysningstradition. I behandlingen af sprog skrev Kunov:

\footnotetext{
"Sproglitteraturen må sammensættes dels ud fra den kulturelle betydning af kendskabet til sproghistorien i almindelighed og hjemlandets sprog i særdeleshed, dels ud fra praktiske hensyn til sprogtilegnelsen.” (Kunov, 1952, 57).
}

Ved siden af den praktiske sprogtilegnelse er det overordnede synspunkt kulturhistorisk. Der anlægges ligeledes en - ganske vist underordnet kulturhistorisk synsvinkel på samfundsvidenskaberne.(2) I sin eksemplifikation af værker af kulturhistorisk betydning nævnte Kunov med en enkelt undtagelse værker af europæiske forfattere som værker, der burde stå på ethvert større bibliotek:

"Det gælder klassiske skrifter som Platons Staten, Thomas Mores Utopia, Karl Marx's og Henry Georges, og nyere oversigtsværker som Heckschers Industrialismen." (Kunov, 1952, 51).

Med hensyn til kunstarterne var Kunovs formål med litteraturen et alment dannelsesformål, der hverken var orienteret mod bestemte kulturområder, nationer eller epoker. Formålet er at udvikle "kunstsans", "kunstforstand", "musikforståelse" og "litteraturforståelse", hvilket dog ikke er udtryk for en ahistorisk forståelse af kunstarterne. (Kunov, 1952, 56-58). I behandlingen af skønlitteraturen tog Kunov udgangspunkt i, at prosalitteraturen, den danske og den oversatte, udgjorde to tredjedele af folkebibliotekernes udlån. I samlingen af prosalitteratur skulle der i folkebibliotekerne generelt lægges størst vægt på nutidslitteraturen. De større biblioteker skulle endvidere have en fyldig repræsentation af litteraturhistoriens navne. Hverken den klassiske nationale litteratur eller den danske samtidslitteratur fremhævedes.

Dette skete derimod i Preben Kirkegaards fremstilling af principper for opbygning af bogbestanden i mindre biblioteker uden uddannede bibliotekarer. Om sognebibliotekers samling af skønlitteratur skrev Kirkegaard:

"Den danske litteratur må danne kærnen i de mindre biblioteker, men oversættelser af fremmed litteratur må selvfølgelig være til stede i rigt mål.” (Kirkegaard, 1958, 74).

De forfattere, der fremhævedes i artiklen tilhører den danske kanon: Holberg, Wessel, Ewald, Oehlenschläger, Grundtvig, Ingemann, Poul Møller, Steen Steensen Blicher, Chr. Winther, H. C. Andersen, Goldschmidt, Herman Bang, J. P. Jakobsen m.fl. 
Med hensyn til faglitteratur lå Kirkegaards opfattelse delvist i tråd med Døssings og Kunovs. For Kirkegaard var det overordnede formål med bogbestanden, at den skulle være grundlaget for en "alsidig, fagligt oplysende og almendannende biblioteksvirksomhed" (Kirkegaard, 1958, 67). Selvom bibliotekssamlingen var lille, burde den have en encyklopædisk profil. På nogle områder var det dog nødvendigt at indskrænke sig til oversigtsværker for at sikre dækningen af hele kundskabsuniverset. Kirkegaards sigte var alment og ikke nationalt fokuseret; heller ikke inden for historie (og geografi), hvor hjemstavnen var fikspunktet.

Springer vi herefter frem til den gældende Bekendtgørelse om Biblioteksvirksomhed (2000), finder vi fortsat et underordnet krav om anskaffelse af danske værker:

$\S 1$. Folkebibliotekerne skal hvert år under hensyn til virkeområdets karakter anskaffe en passende del af udgivne danske værker.

Forskellen mellem de to bekendtg ørelsesformuleringer ligger i, at "udgivne danske værker" i den nugældende bekendtg $\varnothing$ relse ikke alene forstås som sk $\varnothing$ nlitterære. Både indk $\varnothing \mathrm{b}$ af danske faglitterære og danske sk $\varnothing$ nlitterære værker er underkastet kvalitetskravet. Der er således principielt fortsat tale om anskaffelse af det bedste af dansk skønlitteraturs frembringelser.

De ovenstående formåls- og opgaveformuleringer indikerer, at folkebibliotekernes materialevalg og formidling primaert har været og er encyklopædisk orienterede efter 1920.

Som det kan læses ud af de to bekendtgørelser og af Døssings samt Kunovs behandling af bogbestanden, som det indikeres af bibliotekshistoriske undersøgelser (3) og som det fremgår af mønsterkataloger (4) har der også inden for den overordnede encyklopædiske diskurs været en vis tradition for at dække den kanoniserede danske kultur gennem værker, der behandler dansk kunst, arkitektur, litteratur og musik, samt gennem repræsentation af danske (kanoniserede) forfattere. Men generelt må det hævdes, at den danske dannelseskulturelle arv ikke har været en betydningsfuld forståelseskategori i folkebibliotekerne, der netop ikke har en specifik - lovgivningsformuleret - forpligtelse over for den nationale kulturarv. Kirkegaards fremstilling af den skønlitterære bogbestand på sognebibliotekerne danner dog en brudflade i dette billede, et billede der nok ikke helt kan forklares med, at det drejer sig om profilen af sognebibliotekernes bogsamlinger. Der tegner sig altså i nogen grad et felt for yderligere undersøgelser.

\section{Det moderne folkebibliotek og den udvidede kul- turarvsforståelse på biblioteksområdet}

Folkebibliotekerne i moderne forstand, dvs. folkebibliotekerne efter 1920, udspringer af et andet historisk lag end museerne, hvilket er noget af forklaringen på, at det nationale har været nedtonet. Hvor kunstmuseerne (og nationalbibliotekerne) er udsprunget af den politiske og kulturelle nationalisme, der fulgte Den franske Revolution, er det moderne folkebibliotek udsprunget af en folkeoplysningstradition, der blev forbundet med samfundets demokratisering, med trang til kundskab og med selvstændig tænkning.(5) Lidt kortere formuleret: folkebibliotekerne har rødder i en europæisk encyklopædisk oplysningstradition - der ganske vist havde en paternalistisk karakter i 1800tallet og begyndelsen af 1900tallet.

De moderne folkebibliotekers oplysnings- og kulturforståelse kan bestemmes i overensstemmelse med det kulturarvsbegreb, der er formuleret i Vor kulturarv (Krarup et al, 1961 og 1970). Som kulturarven er afgrænset og defineret i dette værk, bygger den på et antikt (græsk-romersk), et kristent og et nordisk grundlag, Vor kulturarv er "den sum af overleverede værdier på alle livets områder, særlig inden for religion, litteratur, videnskab og kunst, som vi alle lever på og tærer på, hvad enten vi véd af det eller ej." (Krarup et al, 1970, Forord).

Ifølge Vor kulturarv er kendskabet til den vestlige, primært europæiske, kulturarv en forudsætning for at vi kan forstå den (fin)kulturelle traditions værker:

"Den, der står fremmed overfor den antikke og den kristne arv, som i vor vesterlandske kultur har indgået en uløselig forbindelse, han forstår så godt som intet af den store digtning, den sto- 
re kunst gennem tiderne. Han kan hverken læse Dante, Shakespeare eller Milton, hverken nogle af vore nordiske landes store digtere $\mathrm{i}$ fortiden eller nutiden. De er nemlig gennemsyret af motiver fra disse verdener. Han forstår hverken noget af Raffael eller Michelangelo eller af nyere kunst. Thi dér er forholdet det samme." (Krarup et al., 1961, 7).

Den første pointe i forhold til folkebibliotekerne er, at det kulturarvsbegreb, der kan siges at omfatte deres formål og intentioner, er europæisk og ikke nationalt i sin horisont. Selvom der i citatet ovenfor er stillet skarpt på absolutte hovedskikkelser i europæisk billedkunst og litteratur, trækker den overordnede definition over mod et antropologisk kulturbegreb (overleverede værdier på alle livets områder). Det er inden for dette spændingsfelt mellem europæisk (vestlig) finkultur og "overleverede værdier på alle livets områder", vi kan bestemme folkebibliotekerne. Sagt lidt anderledes er det en humanistisk forståelse af kulturarv, der har præget folkebibliotekerne.

Den anden pointe hænger sammen med ændringen af, hvad der forstås som kulturarv; det drejer sig ikke blot om den kanoniserede, men også om den fødte kulturarv. Først og fremmest er man på Det kongelige Bibliotek nu også begyndt at opfatte sig som en kulturarvsinstitution. I folkebibliotekerne er der ikke sket en tilsvarende ændring. Det kongelige Bibliotek knytter pligtaflevering sammen med bevaring af kulturarven, jf. titlen: Den trykte kulturarv: Pligtaflevering gennem 300 år, 1998. Førstebibliotekar Grethe Jacobsen et al. (1998) fra Den danske Afdeling på Det kongelige Bibliotek skriver, at pligtafleveringens formål er at dokumentere kulturarven, et formål, der blev blåstemplet af UNESCO i 1981.

Det kongelige Biblioteks direktør, E. Kolding Nielsen, holdt på Danmarks Biblioteksforenings årsmøde i 1999 et foredrag med titlen Nationalbibliotek og kulturarv. I talen lagde Kolding Nielsen megen vægt på, at Det kongelige Bibliotek rummer og forvalter en meget stor del af Danmarks kulturarv: "Nationalbibliotekernes rolle er blevet defineret primært som informationsformidling og som grundlag for informationsoverførsel til brugere. Betydningen af kulturarven har indtil de seneste årtier været nedtonet, og spørgsmålet om, hvordan den skulle formidles, har ikke været på dagsordenen." I talen markeres der således et fokusskift fra informationsformidling over mod forvaltning og formidling af kulturarven. Anderledes formuleret har det at formidle viden inden for den del af landets kulturarv, som biblioteket har ansvaret for, fået en højere prioritet og en højere grad af synlighed.

Til den kulturarv, der er resultatet af 300 års pligtaflevering, er der nu også kommet den elektroniske kulturarv. Det kongelige Biblioteks har ansvaret for netpublikationer og multimedier. Statsbiblioteket modtager radio- og tv-programmer samt fonogrammer som pligtaflevering.

Defineret i pligtafleveringsregi er der intet elitært eller kanoniseret over den danske kulturarv. Den omfatter alle i Danmark producerede dokumenter i et meget bredt spektrum af medier. Der er en radikal forskel mellem det, der gøres til kulturarv gennem udvælgelse, og eksempelvis den trykte kulturarv. Grethe Jacobsen et al. skriver: "Der er langt imellem kunstbøger og de gode romaner blandt de godt 12.000 monografier, som Danske Afdeling, der varetager pligtafleveringen på Det kongelige Bibliotek, årligt katalogiserer. $\mathrm{Og}$ de 12.000 monografier syner ikke af meget blandt de 100.000 stykker småtryk og 90.000 tidsskrifthefter og seriebind, afdelingen modtager." (Jacobsen et al, 1998).

I og med at der skrives om gode romaner og kunstbøger som værker, der skiller sig ud i den store strøm af trykte publikationer, har vi et illustrativt udsagn om dobbeltheden og den indre modsigelse i kulturarvsbegrebet, som det anvendes aktuelt. På den ene side har vi folkebibliotekerne, der trods glidninger fortsætter en europæisk funderet kulturarvstradition (universel oplysning, jf. alsidighedskriteriet) og forvaltningen af et kanoniseret kulturbegreb (jf. kvalitetskriteriet). På den anden side står Det kongelige Bibliotek og Statsbiblioteket, der som pligtafleveringsbiblioteker forvalter den fødte kulturarv (disse biblioteker accessionerer dog eksempelvis på den udenlandske skønlitteraturs område i overensstemmelse med det kanoniserede kulturbegreb, dvs. køber litterære værker af anerkendte forfattere). 


\section{Kunstmuseerne og den nationale kunstneriske kulturarv i et historisk perspektiv}

Om nationalitetstanken skriver kunsthistorikeren Erik Mortensen:

"Nationalitetstanken står som et overordnet begreb gennem hele kunstdebatten i perioden fra sidste fjerdedel af 1700 -tallet til omkring 1880. At samle viden om dansk sprog, historie, natur, digtning og kunst blev tidens måske vigtigste drivkraft.” (Mortensen, 1990, bd. 1, 19).

N. L. Høyen (1798-1870), der var Danmarks første (ekstraordinære) professor i kunsthistorie, lagde vægt på det nordiske og især på det nationale $\mathrm{i}$ sammenhæng med kunsten. Han skelnede mellem kunstnere, der blev i Danmark og dyrkede de nationale motiver, og kunstnere, der drog til udlandet. Han formulerede nogle centrale tanker om national kunst, tanker der fik en lang virkningshistorie:

\begin{abstract}
"Er trangen til nationalitet, til at føle os som danske, til stede, så må den også kunne give sig luft gennem kunsten. Det er altså ikke alene som æstetisk nydelse - den kan være nok så betydelig - at vi dvæler ved kunsten, men som et af de store midler til at styrke, hæve og drage folket; således har den nationale kunst sin begrundelse." (Høyen, 1863; moderniseret retskrivning i kilden).
\end{abstract}

Denne opfordring er siden blevet fulgt af kunstnere, kunstmuseer og kunsthistorikere. På kunstens område indgik Høyens tanker i dannelsen af en nationalromantisk opfattelse af kunsten som kulturarv. Høyens opfattelse blev bekræftet af Julius Lange (1838-96), den første ordinære professor i kunsthistorie. Ifølge Lange besad dansk kunst en egenart, der gav sig udslag i en omhyggelig landskabsgengivelse og en indtrængende menneskeskildring. (Mortensen, 1990, bd. 1, 185). Set fra et senere perspektiv - under Den tyske Besættelse skrev V. Thorlacius Ussing:

"For Nutidsmennesket er det en selvfølgelig Sag, at Følelsen for og Kendskabet til deres Lands Natur udgør en ganske væsentlig Del af deres Tilværelse; ubevidst præges de af Naturen paa det Sted, hvor de fødes og vokser op, bevidst opsøger de senere deres Lands karakteristiske Egne. Naturfølelsen, næret af Digteres og Maleres Værker, er et af de værdifuldeste Klenodier i vor nationale Kultur." (Thorlacius Ussing, 1941, 405).

Thorlacius Ussing redegør for den historiske proces, som har ført frem til, at naturfølelsen næret af digteres og maleres værker er blevet noget, der opfattes som naturligt. Opfattelsen af dansk natur er fortsat nationalt farvet af maleres og forfatteres værker, hvilket kan aflæses af fx Borum \& Scavenius (1986), der samler kunstværker og tekster, som gengiver og fortolker dansk natur.

Den ovenfor karakteriserede opfattelse kan betegnes som nationalromantisk. Opfattelse af den billedkunstneriske kulturarv er opstået som et led i forestillingen om det nationale fra begyndelsen af 1800tallet. Forestillingen om det nationale lå også bag oprettelsen af Det kgl. Billedgallerie på Christiansborg i 1827. Dette billedgalleri, der var forløberen for det nuværende Statens Museum, rummede værker, som repræsenterede italienske og flamske skoler inden for malerkunsten; men der blev også skabt (6) en dansk samling; det at den nationale kunst udskilles og afgrænses, er det centrale. Det kgl. Billedgallerie på Christiansborg var ikke et nationalt kunstmuseum i samme forstand, som det blev det efter Enevældens afskaffelse i 1849. I dette år blev det en statsinstitution med særlige forpligtelser over for den nationale kunst. I 1866 formulerede kultusministeren principperne for indk $\varnothing \mathrm{b}$ til museet. Blandt disse var: "kun saadanne Billeder bør erhverves for Samlingen, som paa en værdig Maade repræsenterer den danske Kunst i dens forskjellige Perioder." (Villadsen, 1998, 69). 


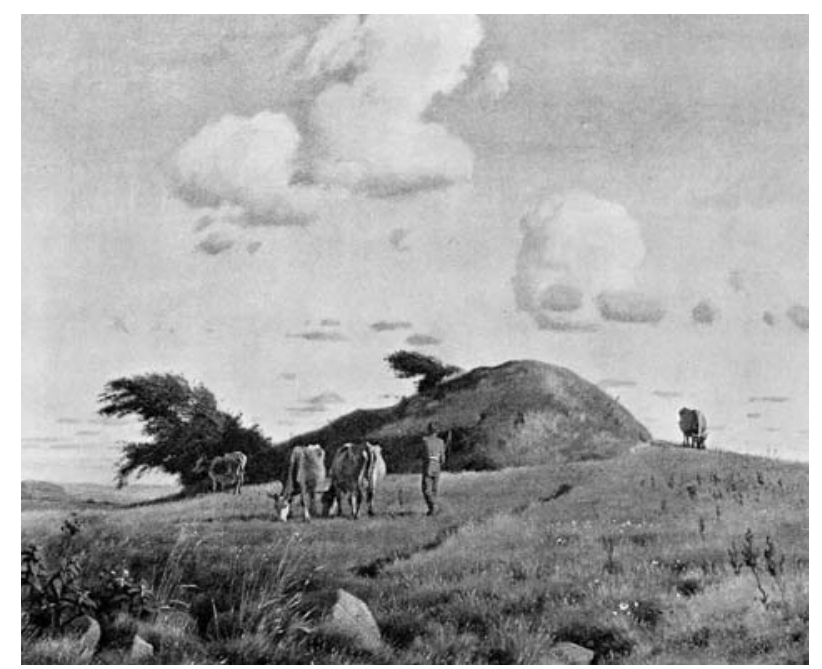

Efterårslandskab - maleren J. Th. Lundbyes danske landskabsmotiv fra 1847 der opfyldte kunsthistorikeren N. L. Hфyens forestillinger om national kunst. Maleriet blev i 1880 med ligeledes nationale begrundelser indk $\phi b t$ af tobaksfabrikanten H. Hirschsprung til den privatsamling som i 1902 blev overdraget til staten.

Denne nationale linje blev fortsat med det nydannede Statens Museum for Kunst, der flyttede ind i den nye museumsbygning i 1896.

"Dannelsen af det nye museum blev dog [på trods af kontroverser, a $\varnothing$ ] skelsættende. Først og fremmest fordi man her langt om længe kunne samle og tilgængeliggøre de nationale billedkunstsamlinger og skabe et monument for den nationale billedkunst." (Villadsen, 1998, 124).

Som monument for den nationale billedkunst blev Statens Museum for Kunst kronen på det værk, som det nationale projekt var på kunstens område. Provinsens kunstmuseer, der blev oprettet fra 1850erne og frem, fik samme nationale fundament (med lokale accenter) som Statens Museum for Kunst. Minna Heimbürger formulerer det således i kapitlet "Fordelingen og arten af vort lands kunstmuseer":

"Bortset fra et par enkelte museer i København og omegn er de danske kunstmuseer bygget op omkring en samling af dansk kunst og har - i hvert tilfælde for de ældre museers vedkommende - sat sig som mål at ville give en oversigt over den danske malerskoles historie " (Heimbürger, 1978, 109).

Blandt undtagelserne nævnes Louisiana, og man kunne tilføje Glyptoteket. Heimbürger hævder endvidere i 1978, at man bortset fra de få undtagelser, "overalt præsenteres for værker af de samme kunstnere." (110-111). Men hun modificerer det en smule ved at skrive, at nogle kunstmuseer har specialiseret sig inden for dansk kunst.

Siden begyndelsen af 1900tallet er den danske billedkunst, specielt den avantgardeorienterede, imidlertid i stigende grad blevet forstået i en europæisk kontekst og i de seneste årtier som 'internationaliseret', som en kunst, der indskriver sig i internationale strømninger frem for i en national kontekst. Men generelt præsenteres avantgardekunsten i en dansk kunsthistorisk kontekst.

I lyset af den nationalromantisk farvede kunstopfattelse lader det sig derfor ikke gøre at betragte den nyere danske avantgardeorienterede kunst som dansk kulturarv i klassisk forstand, ikke kun fordi avantgarden bryder med traditionen og successivt lægger tidligere udtryksmåder og kunstopfattelser bag sig; men også fordi det manglende 'nationale' præg gør det svært at gøre den til kulturarv, med mindre kulturarvsbegrebet omdefineres eller udvides, som det er blevet gjort med begrebet den fødte kulturarv.

Hvad enten man ser kulturarvsproblematikken under en 'essentialistisk' eller en 'konstruktivistisk' synsvinkel, er der en spaltning mellem kunsttraditionen fra den danske 'guldalder' og den internationalt orienterede avantgardekunst. Den førstnævnte betragtes umiddelbart som kulturarv, den sidstnævnte kan ganske vist bruges til at promovere dansk kunst i udlandet, men der er næppe mange, der opfatter den som kulturarv i klassisk forstand. Det gælder derimod umiddelbart de store nationale satsninger på digitalisering af den kunstneriske kulturarv, der først og fremmest koncentrerer sig om det 19. århundredes kunst med hovedfokus på guldalderkunsten (1800-1850). Den internationalt orienterede danske samtidskunst opfattes som en modificeret form for født kulturarv i og med at kriteriet er, at den skabes af danske kunstnere. 
Det kulturarvsbegreb, der aktualiseres i projekter knyttet til eksempelvis "Golden Days in Copenhagen", er finkulturelt; det henviser til den nationalromantiske opfattelse, selvom den overordnede synsvinkel ikke er nationalromantisk. De to kvaliteter, som Høyen tillagde kunsten, nemlig den æstetiske og den nationale, ser ud til at virke sammen, når store projekter som "Guide til dansk guldalder", "Guldalderens billedkunst" og "Flora Danica Online" er blevet sat i værk ud fra kombinationen af et æstetisk kvalitetskriterium og et nationalhistorisk afgrænsnings-kriterium. Gennem denne kombination udpeges de centrale og skelsættende værker.

\section{Bibliotekerne og den europæisk encyklopædiske kulturarv i et historisk perspektiv}

I Danmarks første egentlige biblioteksfaglige afhandling, Christian Molbechs bog Om offentlige Bibliotheker, der udkom et par år efter dannelsen af Det kgl. Billedgallerie på Christiansborg, er det nationale perspektiv helt fraværende. Molbech skriver sig på grundlag af studierejser og 24 års arbejde på Det kongelige Bibliotek ind i den encyklopædiske tradition fra Oplysningstiden. Hans opfattelse af et National-Bibliothek som "Middel-punktet for Landets videnskabelige og selskabelige Cultur" er et bibliotek:

"hvor ingen Videnskab, ingen Green af den menneskelige Aands tænkende Virksomhed, intet Folk eller Sprog, intet Fag af Literaturen, saavidt den er den cultiverede Verdens Eiendom over hele Jordkloden, er eller kan være udelukket -" (Molbech, 1829, 148-149).

Hvad den "cultiverede Verdens Eiendom" omfatter kan udledes af Molbechs tekst. Han begynder med antikken i et biblioteks- og videnskabshistorisk perspektiv, lægger vægt på de store europæiske kulturnationer og inkluderer endvidere litteraturen på "de østerlandske Sprog". Molbechs perspektiv er således encyklopædisk med en forankring i - men ikke en begrænsning til - Europa.

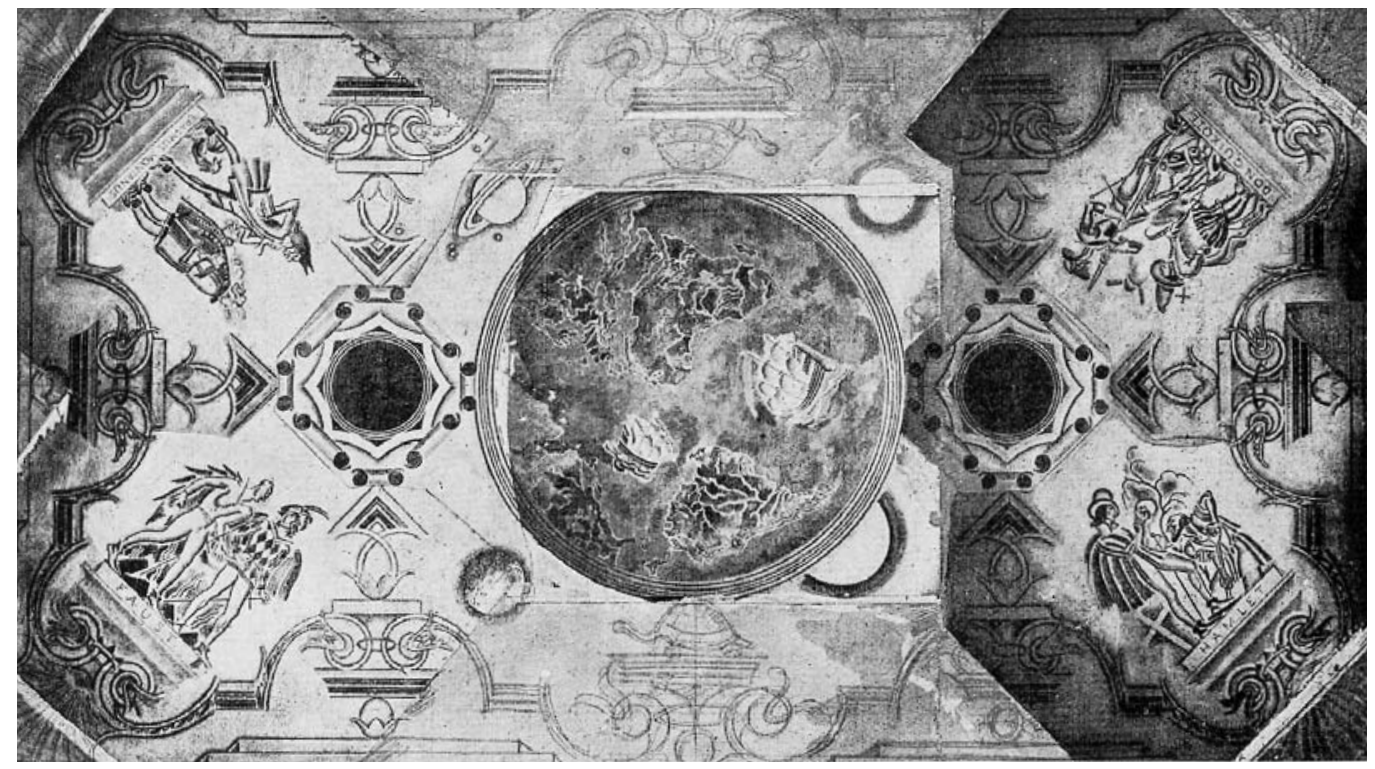

Valdemar Andersens freskoudsmykning af loftet over voksenudlånet i Hjørring Bibliotek fra 1926-27. Motivet er i allegorisk form opdagelsesrejsen i bibliotekets og bøgernes verden, svarende til historiens store opdagelsesrejser og det store verdensrum. I det runde midterfelt vises jordkloden med verdensdelene, som forbindes af to tremastede sejlskibe. Jorden er omgivet af universet og litteraturhistoriens univers: Don Quixote, Hamlet, Faust og Erasmus Montanus. Dekorationerne er praget af tidens Art Deco. Børnelosesalen var udsmykket med motivet De vilde svaner efter H.C. Andersen. Ligesom en senere freskoudsmykning fra 1936 af Niels Larsen Stevns med billeder fra Vendsyssels historie var Valdemar Andersens arbejder bekostet af Ny Carlsbergfondet, som tog initiativ til udsmykning af flere af tidens nybyggede centralbiblioteker og dermed støttede den brede folkeoplysning. 
Hvad angår sognebibliotekerne i 1800tallet skete den største udvikling i kraft af Selskabet for Trykkefrihedens rette Brug. Selskabet blev stiftet i 1835 og ophørte ved Enevældens afskaffelse i 1848-49. Det st $\varnothing$ ttede oprettelsen af sognebiblioteker, hvis antal nåede op over 1000, og udgav en række bøger for "Menigmand" samt en annoteret bibliografi "Fortegnelse over Skrifter til Læsning for Menigmand" (1844). I denne fortegnelse og i Trykkefrihedsselskabets udgivelsespolitik var der også en encyklopædisk profil afpasset for "Menigmand". Profilen omfatter religion og moral, naturkundskab, beskrivelse af folkeslag, lande, egne og stæder, historiske og statistiske skrifter, "Skrifter som meddele Oplysning og Veiledning med Hensyn til borgerlige, huuslige, oeconomiske og techniske Forhold" samt skrifter til almindelig dannelse og underholdning. Sigtet er at gøre først og fremmest - bonden til samfunds- og statsborger samt at danne "Menigmand" (Bruhns \& Ørom, 1990, 63). De anbefalede bøger er ikke blot skrevet af danske forfattere, de inkluderer bl.a. Braminske Leveregler og mange repræsentanter for Oplysningstidens borgerlige roman. Den antikke litteratur vurderes at være uegnet til målgruppen; men der er norrøn litteratur med. I annotationerne til danske skønlitterære værker kommer det nationale ind. Oehlenschläger præsenteres som den nationale digter, hvis sjæl gemmer den nationale følelse og de fædrelandske toner. Overordnet set peger sognebibliotekerne fra midten af 1800tallet frem mod de senere folkebiblioteker, uanset paternalismen og det styrede litteraturudvalg.

\section{Kulturarv, biblioteker og kunstmuseer}

Begrebet kulturarv er først for alvor taget i anvendelse fra 1980erne i den kulturpolitiske og kulturinstitutionelle diskurs; men under andre begreber har den kanoniserede kulturarv været central for både biblioteker og kunstmuseer. I det seneste årti er kulturarvsbegrebet blevet udvidet til at omfatte både den kanoniserede (fin)kulturelle arv og den fødte kulturarv. Denne brede og dobbelte brug af begrebet er slået igennem på biblioteksområdet med opfattelsen af pligtaflevering som kulturarv. På billedkunstens område er den dobbelte begrebsbrug knyttet til henholdsvis kunstmuseerne (kanoniseret kulturarv) og billedkun- stens dokumentations- og biblioteksinstitutioner (født kulturarv).

De danske kunstmuseer udspringer (med undtagelser som fx Glyptoteket) af den politiske og kulturelle nationalisme i begyndelsen af 1800 tallet. Gennem næsten hele perioden siden oprettelsen af Det kgl. Billedgallerie på Christiansborg i 1827 har kunstmuseerne været præget af en kulturel nationalisme, der først i de seneste årtier har været udfordret af en europæisk og international kontekstualisering af kunsten. De danske biblioteker udspringer derimod af en oplysningstradition, der kan føres tilbage til 1700tallet. Denne oplysningstradition er primært europæisk i sin horisont og principielt universel i sit sigte. Christian Molbechs bestemmelse af et "nationalt Bibliotheks" samlinger og funktioner i 1829 sigter ikke på det nationale, men på det universelle. Sognebibliotekerne, der hen imod midten af 1800 tallet blev st $\varnothing$ ttede eller oprettede af Trykkefrihedsselskabet, var ganske vist begrænsede i deres universelle sigte og med et vist præg af nationalisme på skønlitteraturens område; men de kan ses som forløbere for det moderne folkebibliotek (efter 1920), der indskriver sig i en europæisk og universel oplysningsforståelse med en underordnet prioritering af dansk skønlitteratur og dansk historie i bred betydning. Denne forståelse kan der for det moderne folkebiblioteks vedkommende argumenteres for ud fra både formålsformuleringer i bibliotekslovgivningen, bibliotekarers fremstillinger af principper for bogvalg og bestandssammensætning, mønsterkataloger og undersøgelser af konkrete folkebibliotekers samlingsprofiler. Men mindre brudflader i denne forståelse lægger op til yderligere unders $\varnothing$ gelsesarbejde.

Tak til Bruno Kjær for flere former for hjælp.

\section{Noter}

1. På konferencen "Dansk identitet i det 21 . århundrede", den 3. september 1999.

2. Det væsentligste er at oplysningen inden for samfundskundskabsområdet ses $\mathrm{i}$ et alment perspektiv, der drejer sig om forskellige opfattelser inden for samfundstænkningen: Konservatisme, radikalisme, kommunisme, georgeis- 
me. Der er ingen betoning af litteratur om det danske samfund. Kunov, 1952, 51.

3. Boel, K et al.: "Selv se, selv unders $\phi$ ge, selv toenke.." Det nordjyske Landsbiblioteks historie 1895-1995. Aalborg : Det nordjyske Landsbibliotek, 1995. Emerek, L.: Sund og sand oplysning. Kapitler af Hjørrings bibliotekshistorie 1901-2001. Hjørring : Hjørringbogen, 2001.

4. Den store mønsterkatalog. Bind 1-2. København : Bibliotekscentralen, 1965-73.

5. Her parafraseret over Andr. Sch. Steenbergs Vore Folkebogsamlinger. 1900, kapitlet: Folkebogsamlinger.

6. Villads Villadsen skriver: "Han (Joan Conrad Spengler, der indrettede galleriet) skabte endvidere en dansk skole, der for 1600- og 1700tallets vedkommende $\mathrm{i}$ vidt omfang måtte bestå af danske der havde virket i udlandet, og udlændinge, der havde virket i Danmark (...) og en lille repræsentation af nyere dansk maleri (...)”. Villadsen, 1998, 38.

\section{Litteratur}

Boel, K et al. "Selv se, selv undersøge, selv tanke..": Det nordjyske Landsbiblioteks historie. Aalborg: Det nordjyske Landsbibliotek.

Borum, P \& Scavenius, B (1986). Malernes og forfatternes Danmark: dansk natur / malerier udvalgt af Bente Scavenius ; tekster udvalgt af Poul Borum. København : Dansk Bogtjeneste.

Bruhns, S \& Ørom, A (1990). At kunne skelne lys fra lygtemænd : Om J. W. Marckmanns Fortegnelse over Skrifter til Læsning for Menigmand. Bibliotekshistorie, 3. København : Dansk Bibliotekshistorisk Selskab, 44-89.

Bunkenborg, C \& Lommer, K (1995). Kunstmuseer og billedkunst ved en kulturpolitisk skillevej. Århus : Klim.

Det Digitale Studiearkiv 2000 : Dokumentation af dansk billedkunst gennem de sidste ca. 30 år. Lokaliseret den 27. august 2003 på World Wide Web: http://www.kulturnet.dk/omknetvenstre1041p.html

Dupont, H (1998). Om kort og billeder i pligtafleveringens historie. Den trykte kulturarv : Pligtaflevering gennem 300 år. Redigeret af H Horstbøll og J T Lauridsen. København : Museum Tusculanums Forlag, 141-167.

Døssing, T (1929). Folkebibliotekerne. Dansk Folkeopdragelse. Redigeret af A Boje, E J Borup og H Rützebeck. København : Martins Forlag, 233250.

Døssing, T (1942). Folkebibliotekerne. Dansk Folkeoplysning. Redigeret af O Bertolt, A Boje og E J Borup. København : Martins Forlag, 207-227.

Emerek, L (2001). Sund og sand oplysning : Kapitler af Hjørrings bibliotekshistorie 1901-2001. Hjørring : Hjørringbogen.

Flora Danica Online. Lokaliseret den 25. august 2003 på World Wide Web:

http://www.pictures.dnlb.dk

Guide til dansk guldalder. Lokaliseret den 25. august 2003 på World Wide Web:

http://www.guldalderbilleder.dk.

Guldalderens billedkunst - en billeddatabase. Lokaliseret den 25. august 2003 på World Wide Web: http://www.guldalderbilleder.dk.

Heimbürger, M (1978). Hvad er der galt?: Kunstmuseernes problemer. København : Gyldendal.

Helleland, A (2000). Den moderne danskers identitet. Indtryk, 4, December 2000-februar 2001, 2.

Høyen, N L (1863). Om national kunst. Lokaliseret den 28. august 2003 på World Wide Web: http://www.nomos-dk/skraep/hoeyen.htm

Jacobsen, G, Olsen, S \& Eirikson, J (1998). Pligtaflevering: bevaring af kulturarven. Bogens Verden 87 (6), 36-39. Lokaliseret den 27. august 2003 på World Wide Web:

http://www.kb.dk/guets/natl/db/bv/98/6/1998_06_3 6.htm 
Kirkegaard, P (1958). Principper for opbygning af bogbestanden. Håndbog for mindre biblioteker. 2 . ændrede udgave redigeret af M Iversen. København : Dansk bibliografisk Kontor, 65-75.

Krarup, P et al (1961). Vor kulturarv: Kulturgrundlaget I. København: Forlaget for Faglitteratur.

Krarup, P et al (1970). Vor kulturarv: Nutidskulturen $V$. København : Forlaget for Faglitteratur.

Kolding Nielsen, E (1999). Nationalbibliotek og kulturarv. Bogens Verden 88 (4), 3-7.

Kulturarv (2002). Den Store Danske Encyklopaedi, Supplementsbind. København: Danmarks Nationalleksikon.

Kunov, N (1952). Bogvalg og bogbestand. København : Folkebibliotekernes bibliografiske Kontor.

Lov om biblioteksvirksomhed. 2000. Lokaliseret den 17. november 2003 på World Wide Web: http://www.bs.dk/index.ihtml? side=http://www.bs. $\mathrm{dk} / \mathrm{vis} \_$pub.ihtml? id=861_fil=http://www.bs.dk/lo vstof/lov340.htm\&pid $=0$

Lov om statsunderst $\varnothing$ ttede Biblioteker af 5. marts 1920 med dertil hørende Bekendtgørelser. København : Statens Bibliotekstilsyn, 1921.
Molbech, C (1829). Om offentlige Bibliotheker, Bibliothekarer, og det, man har kaldet Bibliotheksvidenskab. København : Gyldendal.

Mortensen, E (1990). Kunstkritikkens og Kunstopfattelsens Historie i Danmark I-II. København : Rhodos.

Regeringens redegørelse til Folketinget om kulturpolitik. (1997). København: Kulturministeriet, J.nr. 1997.100-5.

Den store mønsterkatalog (1965). Redigeret af S Dahl under medvirken af A Tiedje. København: Bibliotekscentralen.

Den store mønsterkatalog II (1973). Redigeret af A Tiedje. København : Bibliotekscentralen.

Thorlacius Ussing, V (1941). Kunst på Skagen. Danmark 12, 405-416.

Villadsen, V (1998). Statens Museum for Kunst 1827-1952. København: Statens Museum for Kunst \& Gyldendal.

Aagesen, D (2002). Avantgarde i dansk og europoeisk kunst 1909-19. København: Statens Museum for Kunst. 